Scientific Note

\title{
New Tachinidae parasitoid records for Mesomphaliini (Coleoptera: Chrysomelidae: Cassidinae) in the Neotropical region
}

\author{
Nuevos registros de parasitoides Tachinidae en Mesomphaliini (Coleoptera: Chrysomelidae: \\ Cassidinae) en la región Neotropical
}

Ronaldo Toma $^{1}$ and Thiago Marinho Alvarenga ${ }^{2}$ (D)

${ }^{1}$ Fiocruz - Mato Grosso do Sul, Rua Gabriel Abrão, 92, CEP 79081-746, Jardim das Nações, Campo Grande, MS, Brasil.鼻rtkuna1@gmail.com

${ }^{2}$ Research associate at the LEIA - Laboratório de Ecologia de Interações e Agroecossistemas - Instituto de Biologia da Universidade Estadual de Campinas - UNICAMP Cidade Universitária Zeferino Vaz - Rua Monteiro Lobato, 255 - Campinas - SP - Brasil - CEP 13083-862. E-mail: marinho.bio@gmail.com

\section{ZooBank: urn:lsid:zoobank.org:pub:81D81D9F-6BEF-43C3-B86A-22B570E321DC https: / / doi.org/10.35249/ rche.46.4.20.15}

\begin{abstract}
New records of Tachinidae flies parasitizing Mesomphaliini species (Coleoptera: Chrysomelidae: Cassidinae) collected in the Neotropical region. We provided the first records of parasitism of Cyrtonota thalassina (Boheman, 1850), Botanochara sp. and Paraselenis flava (Linnaeus, 1758) by species of Eucelatoria Townsend, 1909 (Blondeliini) and parasitism of $P$. flava by a species of Voria Robineau-Desvoidy, 1830 (Voriini). A species of Eucelatoria parasitizing Chelymorpha sp. is recorded for Brazil for the first time. New host plant records are provided: C. thalassina on Ipomoea saopaulista O'Donell and P. flava on I. aristolochiifolia G. Don.
\end{abstract}

Key words: Blondeliini, Brazil, Ipomoea, subsocial, Voriini.

Resumen. Nuevos registros de moscas Tachinidae parasitando especies de Mesomphaliini (Coleoptera: Chrysomelidae: Cassidinae) recolectadas en la región Neotropical. Proporcionamos los primeros registros de parasitismo de Cyrtonota thalassina (Boheman, 1850), Botanochara sp. y Paraselenis flava (Linnaeus, 1758) por especies de Eucelatoria Townsend, 1909 y parasitismo de P. flava por una especie de Voria Robineau-Desvoidy, 1830 (Voriini). Se registra por primera vez para Brasil una especie de Eucelatoria parasitando Chelymorpha sp. Se proporcionan nuevos registros de plantas hospedantes, C. thalassina sobre Ipomoea saopaulista O'Donell y P. flava sobre I. aristolochiifolia G. Don.

Palabras clave: Blondeliini, Brasil, Ipomoea, subsocial, Voriini.

Mesomphaliini (Coleoptera: Chrysomelidae) is the second-largest tribe of Cassidinae $s$. str. ("tortoise beatles" not including Hispinae s. str.), comprising about 555 species classified into 25 genera (Borowiec and Świętojańska 2018). Species occur predominantly in South America, with few species also distributed in North and Central America (Borowiec and Świętojańska 2018). Members of this tribe are phytophagous, which monophagous or oligophagous species are usually associated with Convolvulaceae and Asteraceae, many of them recorded feeding on species of Ipomoea L. (Convolvulaceae) (Jolivet 1988; Buzzi 1994; Borowiec and Świętojańska 2018).

Received 3 October 2020 / Accepted 24 November 2020 / Published online 23 December 2020

Responsible Editor: José Mondaca E. 
Most Mesomphaliini exhibit solitary behavior, but larval gregariousness occurs in subsocial and non-subsocial species (Chaboo et al. 2014). Subsocial behavior, displayed as maternal care of immatures, is documented for at least 32 species of three genera of this tribe (not including Eugenysini): Acromis Chevrolat, 1836, Omaspides Chevrolat, 1836, and Paraselenis Spaeth, 1913 (Chaboo et al. 2014; Macedo et al. 2015; López-Pérez 2017; Leocádio et al. 2020).

All tachinid flies with known life histories are parasitoids of other arthropods, mainly insects, including Coleoptera (Wood 1985). Cassidinae s. str. is the most frequently parasitized subfamily within Chrysomelidae, with Hymenoptera and Tachinidae listed as the major parasitoids for the group (Cuignet et al. 2008). However, there are few records of tachinid parasitoids for the Cassidinae in the Neotropical region (Buzzi 1988). Except for the record of Ebenia Macquart, 1846 parasitizing Chelymorpha alternans Boheman, 1854, the records of parasitism of Mesomphaliini by Tachinidae used to be attributed to the genus Eucelatoria Townsend, 1909 (Boldt et al. 1991; Cox 1994; Buzzi 1994; OlivaresDonoso et al. 2000; Nogueira-de-Sá and Vasconcellos-Neto 2003; Cuignet et al. 2008).

Fieldwork was carried out by Thiago Marinho Alvarenga in the municipalities of Campinas and Jundiaí (Serra do Japí), state of São Paulo, Brazil, from January 2012 to December 2018. Fifth instar larvae of tortoise beetles were collected from species of Ipomoea and reared in laboratory on sterilized leaves of the same host plants. In few days, it was observed that some of them were infected with tachinid larvae, which later completed their development cycle, killing the hosts.

Tachinid pupae collected from larvae, prepupae, and pupae of tortoise beetles were reared to obtain adults for identification. Adult tachinids were identified according to Thompson (1961), Wood (1985), Cortés and Gonzalez (1989), Wood and Zumbado (2010), Fleming et al. (2017), and Burington (2017), while Mesomphaliini adult specimens were determined using the taxonomic key provided by Borowiec and Świętojańska (2018). Diptera voucher specimens $(n=15)$ were deposited at the Zoological Collection of Universidade Federal de Mato Grosso do Sul, Brazil (ZUFMS).

We recorded species of the genus Eucelatoria (Blondeliini) parasitizing Cyrtonota thalassina (Boheman, 1850), Botanochara sp., Chelymorpha sp., and Paraselenis flava (Linnaeus, 1758), and a species of Voria Robineau-Desvoidy, 1830 (Voriini) parasitizing three specimens of $P$. flava. The fifth instar larvae, prepupae, and pupae became dark when infected by tachinid flies (Figs. 1A, 1B). We also registered I. aristolochiifolia G. Don as host plant of $P$. flava for the first time. The association was previously recorded for I. batatas (L.) Lam. and I. purpurea (L.) Roth (Montes and Raga 2010; Borowiec and Świętojańska 2018).

Cyrtonota thalassina occurs in Argentina, Brazil (Pará, from Minas Gerais to Rio Grande do Sul) and Paraguay (Simões and Monné 2011; Borowiec and Świętojańska 2018). Biological information of Cyrtonota juvenile stages is only known for four species (Buzzi 1988; Buzzi et al. 2000; Cedeño-Loja and Chaboo 2020), including C. thalassina. This species has solitary larvae and pupae. The observation of Eucelatoria sp. 1 (one female from Jundiaí) represents the first record of a tachinid species parasitizing this genus. Cyrtonota thalassina was collected on Ipomoea saopaulista $\mathrm{O}^{\prime}$ Donell for the first time. Associations were firstly recorded on I. grandifolia (Dammer) O'Donell and I. purpurea (Borowiec and Świętojańska 2018; Gomes 2018).

As well as for the other Cassidinae s. str. genera, there are few studies on the life history of Botanochara. Species collected in this study has solitary fifth instar larvae. Eucelatoria sp. 2 (one female from Campinas) is the first record of a tachinid species parasitizing the genus Botanochara. The host was collected on I. aristolochiifolia.

Despite the wide distribution and abundance of Chelymorpha species in the Neotropical region, less than a dozen species have their life histories known (Morrison and Windsor 
2018). Chelymorpha species were already reported as Eucelatoria host: Chelymorpha cassidea Fabricius, 1775 parasitized by Eucelatoria dimmocki (Aldrich, 1932) in the United States (Aldrich 1932) and Chelymorpha varians (Blanchard, 1851) parasitized by Eucelatoria parkeri (Sabrosky, 1952) in Uruguay and Chile (Sabrosky 1952; Olivares-Donoso et al. 2000). In Panama, reports were made on Chelymorpha alternans adults parasitized by a species of Eucelatoria, while larval and pupal stages were parasitized by Ebenia sp. and two other unidentified tachinid species (Cuignet et al. 2008). Chelymorpha sp. larvae and pupae collected in this work displayed gregarious behavior. This parasitism by a tachinid species, Eucelatoria sp. 3 (two males and two females from Campinas), is recorded for Brazil for the first time. Chelymorpha sp. was collected associated with Ipomoea sp.
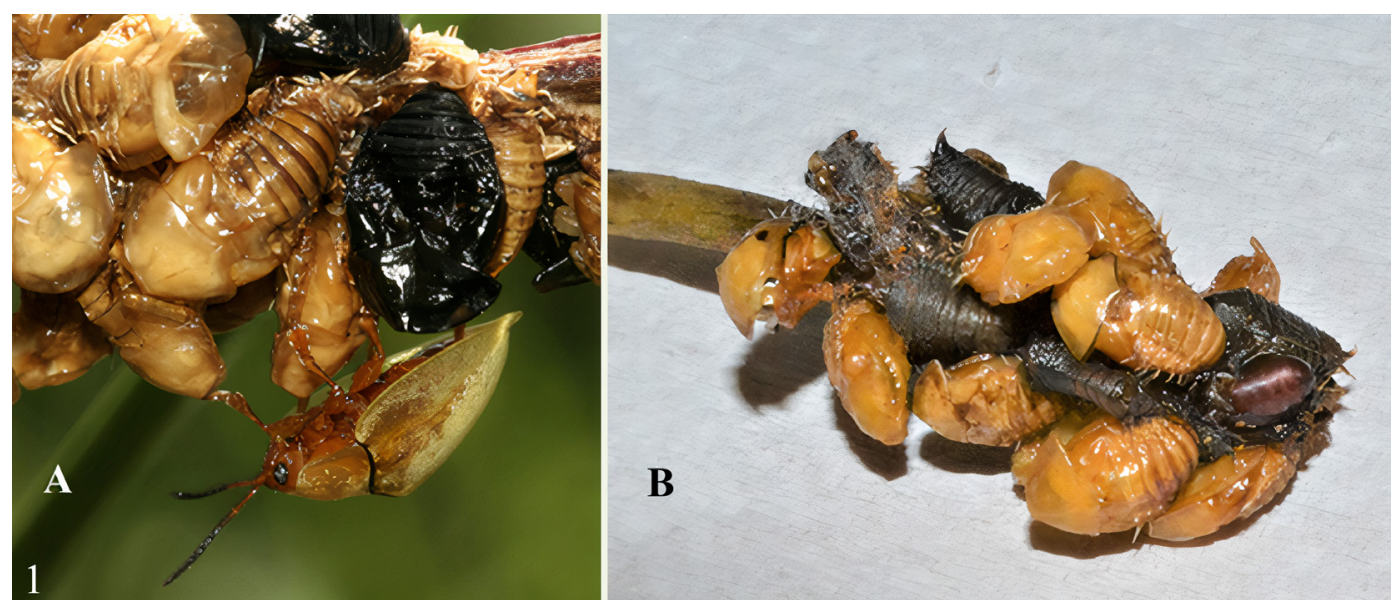

Figure 1. A. Female of Paraselenis flava (Linnaeus, 1758) guarding offspring (pupae). B. Pupae of $P$. flava parasitized with Eucelatoria sp. (pupa), collected from Ipomoea batatas (L.) Lam.

Subsocial behavior is documented for ten species of Paraselenis, including P. flava, an important pest of Ipomoea batatas (sweet potato) in Brazil (Montes and Raga 2010; Chaboo et al. 2014; Leocádio et al. 2020). Cuignet et al. (2008) recorded a species of Eucelatoria (Diptera: Tachinidae) parasitizing Paraselenis tersa (Boheman, 1854) in Panama. In Brazil, an unidentified tachinid species was observed parasitizing larvae of Paraselenis aulica (Boheman, 1854) and Paraselenis dichroa (Germar, 1824) (Macedo et al. 2015; Cuozzo et al. 2017). Here we record for the first time the occurrence of two tachinid species, Eucelatoria sp. 4 (three males and three females from Campinas) parasitizing P. flava on I. batatas and I. aristolochiifolia, and Voria sp. (one male and two females from Campinas) parasitizing $P$. flava on I. aristolochiifolia (Figs. 2A-2H).

\section{Consideration on parasitoid flies:}

Voriini species have been recorded as parasitoids mainly on larvae of Noctuidae and Uraniidae (Lepidoptera) (Fleming et al. 2017). Occasionally sawfly larvae (Hymenoptera) have already been recorded parasitized by Voriini species (Thompson 1961), although this record is doubtful according to Herting (2017). The parasitism of Coleoptera by Voria had never been recorded until this study. For Lepidoptera, females of Voria lay incubated eggs directly on the host larvae. Hatching and penetration of the tachinid first instar larvae occur a few minutes after oviposition (Thompson 1915; Elsey and Rabb 1970). The specimens of Voria sp. fit with the redescription of Voria ruralis (Fallén, 1810) by Thompson (1961), but slightly differ in few color aspects. According to Fleming et al. (2017), species of 
Voria are remarkably similar, presenting subtle differences in the head coloration and male terminalia morphology. Identification through molecular methods suggests that $V$. ruralis represents a species complex.

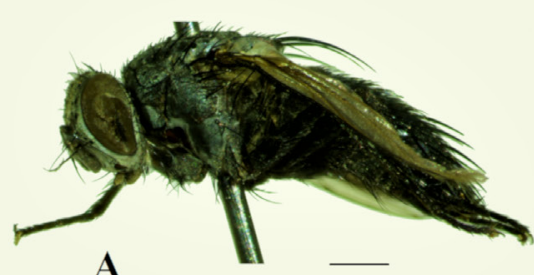

A
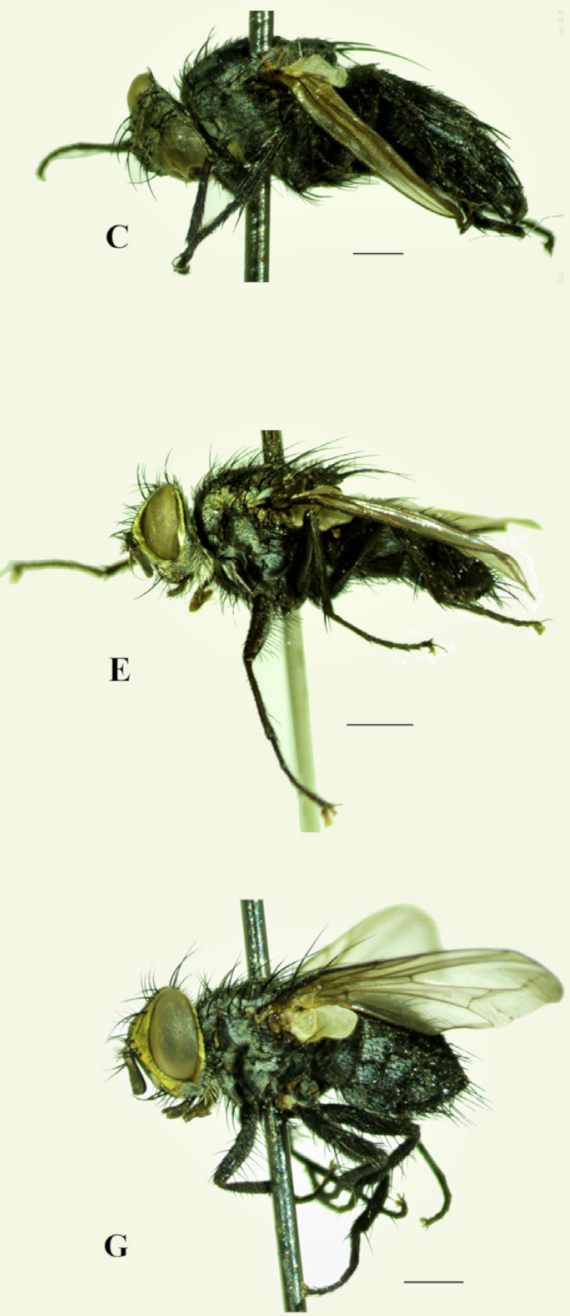
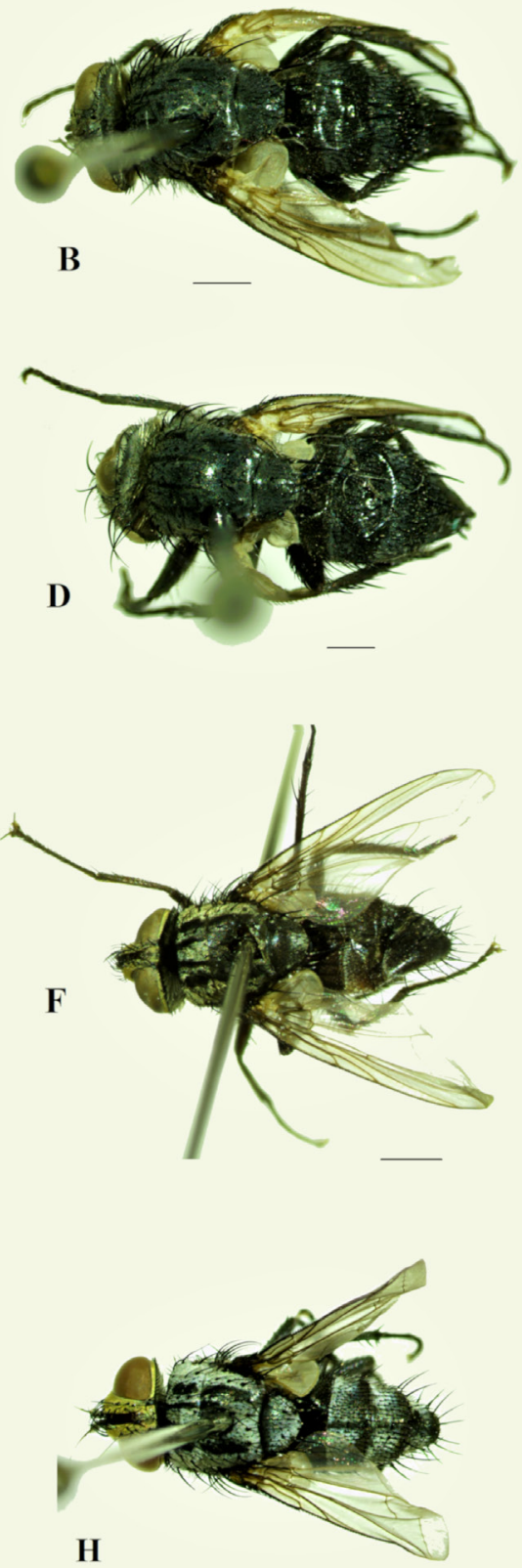

H

\section{2}

Figure 2. A-B. Voria sp., male in lateral and dorsal views. C-D. Voria sp., female in lateral and dorsal view. E-F. Eucelatoria sp., male in lateral and dorsal views. G-H. Eucelatoria sp., female in lateral and dorsal views. Scale bar: $1 \mathrm{~mm}$. 
Eucelatoria is one of the largest genera of Blondeliini restricted to the New World, with more than 50 described species. Most host records consist in Lepidoptera larvae, although there are few species known to infect larvae of Chrysomelidae beetles (Wood and Zumbado 2010). Including the new records, Eucelatoria species parasite 16 genera of four Cassidinae s. str. tribes (Cassidini, Ischyrosonychini, Omocerini, and Mesomphaliini), from solitary to subsocial species, including species of seven Mesomphaliini genera (Anacassis Spaeth, 1913, Botanochara, Chelymorpha, Cyrtonota, Omaspides, Paraselenis, and Stolas Billberg, 1820) (Boldt et al. 1991; Cox 1994; Buzzi 1994; Olivares-Donoso et al. 2000; Nogueira-de-Sá and Vasconcellos-Neto 2003; Cuignet et al. 2008). Females of Eucelatoria lay incubated eggs directly inside the host using the sternite 7 modified into a hook-like piercer (Stireman et al. 2006; Wood and Zumbado 2010).

Eucelatoria species recorded here belong to the Eucelatoria dimmocki species group according to Burington (2017) identification key and share the following combination of characters with this group: apical scutellar bristles present, prosternum with black setae, only one anterodorsal bristles on mid tibia, parafacial bare, katepisternum with three bristles, fore tibia lacking posterodorsal bristles, and postpronotal bristles arranged in triangle.

\section{Literature Cited}

Aldrich, J.M. (1932) Records of dipterous insects of the family Tachinidae reared by the late George Dimmock, with description of one new species and notes on the genus Anetia Robineau-Desvoidy. Proceedings of the United States National Museum, 80: 1-8.

Boldt, P.E., Cordo, H.A. and Gandolfo, D. (1991) Life history of Stolas (Anacassis) fuscata (Klug) (Coleoptera: Chrysomelidae) on seepwillow, Baccharis salicifolia (R.\&P.) Pers. (Asteraceae). Proceedings of the Entomological Society of Washington, 93: 839-844.

Borowiec, L. and Świętojańska, J. (2018) World Catalog of Cassidinae, Wrocław, Poland. Accessed July 1, 2020. Available in: http://www.cassidae.uni.wroc.pl/katalog\%20 internetowy/index.htm

Burington, Z. (2017) Evolution and biogeography of the Tachinid Flies with focus on the Tribe Blondeliini (Insecta: Diptera: Tachinidae). Thesis (Doctor of Phylosophy). Wright State University. Fairborn, OH, USA.

Buzzi, Z.J. (1988) Biology of Neotropical Cassidinae. pp. 559-580. In: Jolivet, P., Petitpierre, E. and Hsiao, T.H. (eds.) Biology of Chrysomelidae. Kluwer Academic Publishers, Dordrecht/ Boston/London.

Buzzi, Z.J (1994) Host plants of Neotropical Cassidinae. pp. 205-212. In: Jolivet, P.H., Cox, M.L. and Petitpierre, E. (eds.) Novel aspects of the biology of Chrysomelidae. Springer Science+Business Media Dordrecht, Dordrecht.

Buzzi, Z.J, Frieiro-Costa, F.A. and Filho, M.F. (2000) Imaturos de Cyrtonota conglomerata (Boheman, 1862) (Coleoptera: Chrysomelidae: Cassidinae). Revista Brasileira de Entomologia, 44: 21-26.

Cedeño-Loja, P.E. and Chaboo, C.S. (2020) Natural history notes on Cyrtonota sericinus (Erichson, 1847) in Ecuador (Coleoptera: Chrysomelidae: Cassidinae: Mesomphaliini). Revista Peruana de Biología, 27: 127-130.

Chaboo, C.S., Frieiro-Costa, F.A., Gómez-Zurita, J. and Westerduijn, R. (2014) Origins and diversification of subsociality in leaf beetles (Coleoptera: Chrysomelidae: Cassidinae: Chrysomelinae). Journal of Natural History, 48: 2325-2367.

Cortés, P. and González, A. (1989) Generos Voriinos de Taquinidos chilenos (Diptera: Tachinidae: Voriini). Memórias do Instituto Oswaldo Cruz, 84: 115-123.

Cox, M.L. (1994) The Hymenoptera and Diptera parasitoids of Chrysomelidae. pp. 419467. In: Jolivet, P.H., Cox, M.L. and Petitpierre, E. (eds.) Novel aspects of the biology of Chrysomelidae. Springer Science+Business Media Dordrecht, Dordrech. 
Cuignet, M., Windsor, M.D., Reardon, J. and Hence, T. (2008) The diversity and specificity of parasitoids attacking Neotropical tortoise beetles (Chrysomelidae: Cassidinae). pp. 345-367. In: Jolivet, P.H., Santiago-Blay, Jorge A., and Schmitt, M. (eds.) Research on Chrysomelidae. Leiden: The Netherlands.

Cuozzo, M.D., Frieiro-Costa, F.A. and Souza, B. (2017) Life history of Paraselenis (Spaethiechoma) dichroa Germar 1824 Coleoptera Chrysomelidae Cassidinae in natural conditions of Atlantic Forest from Brazil. Journal of Natural History, 51: 9-10.

Elsey, K.D. and Rabb, R.L. (1970) Biology of Voria ruralis (Diptera: Tachinidae). Annals of the Entomological Society of America, 63: 216-222.

Fleming, A., Wood, D., Smith, M., Dapkey, T., Hallwachs, W., and Janzen, D. (2017) A new species of Voria Robineau-Desvoidy (Diptera: Tachinidae) from Area de Conservación Guanacaste in northwestern Costa Rica. Biodiversity Data Journal, 5: e20123. https:/ / www.doi.org/10.3897/BDJ.5.e20123

Gomes, P.A. de A. (2018) História natural de Cassidinae Gyllenhal, 1813 sensu stricto (Coleoptera: Chrysomelidae) na Floresta Nacional de Passa Quatro -MG. Tese apresentada à Universidade Federal de Lavras, como parte das exigências do Programa de Pós-Graduação em Entomologia, para a obtenção do título de Doutora. Universidade Federal de Lavras, Brasil.

Herting, B. (2017) A critical revision of host records of Palearctic Tachinidae (Diptera) until 1937. Stuttgarter Beiträge zur Naturkunde A, 10: 41-173. https: / / doi.org/10.18476/sbna. v10.a3

Jolivet, P.H. (1988) Food habits and food selection of Chrysomelidae bionomic and evolutionary perspectives. pp. 1-20. In: Jolivet, P., Petitpierre, E. and Hsiao, T.H. (eds.) Biology of Chrysomelidae. Kluwer Academic Publishers, London.

Leocádio, M., Simões, M.V.P., Sekerka, L., Schrago, C.G., Mermudes, J.R.M. and Windsor, D.M. (2020) Molecular systematics reveals the origins of subsociality in tortoise beetles (Coleoptera: Chrysomelidae: Cassidinae): Evolution of subsociality in Cassidinae. Systematic Entomology, 45: 894-910.

López-Pérez, S. (2017) Aspectos sistemáticos y biológicos de Cassidinae Gyllenhal, 1813 (Coleoptera: Chysomelidae). Dugesiana, 24: 35-46.

Macedo, M.V., Flinte, V., Abejanella, A. and Chaboo, C.S. (2015) Three new reports of subsocial tortoise beetles from South America (Chrysomelidae: Cassidinae). Annals of the Entomological Society of America, 108: 1088-1092.

Montes, S.N.M. and Raga, A. (2010) "Fusquinha" Paraselenis flava (L. 1758) praga da batata doce. Instituto Biologico - APTO, Documento Técnico, 4: 1-8.

Morrison, C.R. and Windsor, D.M. (2018) The life history of Chelymorpha alternans (Coleoptera: Chrysomelidae: Cassidinae) in Panamá. Annals of the Entomological Society of America, 111: 31-41.

Nogueira-de-Sá, F. and Vasconcellos-Neto, J. (2003) Natural enemies of Neotropical Cassidinae (Coleoptera: Chrysomelidae). pp. 161-173. In: Furth, D.G. (ed.) Special Topics in Leaf Beetle Biology. Pensoft, Moscow.

Olivares-Donoso, R., Fuentes-Contreras, E. and Niemeyer, H.M. (2000) Identificación de parasitoides de Chelymorpha varians Blanchard (Coleoptera: Chrysomelidae: Cassidinae) en una localidad de Chile central. Revista Chilena de Entomología, 27: 65-69.

Sabrosky, C.W. (1952) New larvaevorid fly parasitic on tortoise beetles in South America (Diptera). Journal of the Washington Academy of Sciences, 42: 325-327.

Simões, M.V.P. and Monné, M.L. (2011) Inventário das espécies de Cassidinae (Insecta: Coleoptera: Chrysomelidae) do Parque Nacional do Itatiaia, RJ, Brasil. Biota Neotropica, 11: 215-228.

Stireman, J.O., O'Hara, J.E. and Wood, D.M. (2006) Tachinidae: evolution, behavior, and ecology. Annual Review of Entomology, 51: 525-555. 
Thompson, W.R. (1915) Sur les caracteres anatomiques et ethologiques des tachinaires du genre Plagia Meig. Comptes rendu de la Société de biologie et de ses filiales, 78: 671-674.

Thompson, W.R. (1961) The Tachinids (Diptera) of Trinidad. I. The Voriines. Transactions of the American Entomological Society, 87: 21-44.

Wood, D.M. (1985) A taxonomic conspectus of the Blondeliini of North and Central America and the West Indies (Diptera: Tachinidae). Memoirs of the Entomological Society of Canada, 132: 1-130.

Wood, D.M. and Zumbado, M.A. (2010) Tachinidae (tachinid flies, parasitic flies). pp. 1343-1417. In: Brown, B.V., Borkent, A., Cumming, J.M., Wood, D.M., Woodley, N.E. and Zumbado, M. (eds.) Manual of Central American Diptera. Volume 2. NRC Research Press, Ottawa. 